\title{
Nobel panel rewards prion theory after years of heated debate
}

[London] The 1997 Nobel Prize in Physiology and Medicine was awarded this week to Stanley Prusiner of the University of California, San Francisco, for his contributions towards the identification of the infectious agent that causes transmissible spongiform encephalopathies (TSEs). This class of disease includes BSE in cows, scrapie in sheep and Creutzfeldt-Jakob disease and its new variant in humans.

The award has been greeted with delight for Prusiner by scientists across the world. Charles Weissmann of Zurich University says he is convinced that Prusiner "deserves the prize" and is "very pleased", while Colin Masters of the Walter and Eliza Hall Institute in Melbourne, Australia, describes Prusiner's work as "terrific".

But the award has also generated some surprise, as Prusiner's ideas remain unproven. It is widely agreed that TSEs are most probably caused by a completely new type of agent that does not contain nucleic acids. But the infectious agent remains unknown, and there is some concern in the scientific community that the Nobel Assembly may be prematurely endorsing what remains a hypothesis, however appealing.

It was 21 years ago - at the beginning of Prusiner's research career - that Carleton Gajdusek was made a Nobel laureate for demonstrating that human spongiform encephalopathies can be transmissible diseases. Since then, Prusiner has been one of the leaders of attempts to determine the agent which is responsible for this infectivity, and which he claims is an abnormal form of the host PrP protein. Somehow the disease form of this protein is able to catalyse its own formation by converting its normal, cellular homologue into the disease form.
This hypothesis, known as the proteinonly hypothesis, implies a simple disease agent - which Prusiner called the 'prion', a rather tortured acronym of 'small proteinaceous infectious particle' - distinct from all known disease agents. The difference is that the prion probably does not contain nucleic acid, unlike bacteria, viruses, fungi and multicellular parasites.

In the 1980s Prusiner championed the protein-only hypothesis in the face of hostile criticism, at a time when many scientists were convinced that all life-forms needed nucleic acid to replicate. Those close to the debate at the time say that the severity of the criticism directed at Prusiner was extraordinary, and obviously had an impact on him.

The idea of a proteinaceous agent for TSEs was first suggested in 1966 by Tikvah Alper, working for the Medical Research Council at the Hammersmith Hospital in London, who found that ultraviolet radiation that destroys all nucleic acid does not destroy scrapie infectivity (see Nature 214, 764-766; 1966).

The following year, J. S. Griffith at Bedford College, London, proposed that infectivity in scrapie could be due to the altered conformation of a normal cellular protein (see Nature 215, 1043-1044). Almost a decade later, Prusiner developed these ideas by producing compelling biochemical analyses to confirm his views and defended them rigorously against strong criticisms.

Prusiner's career has involved many productive collaborations with scientists who have been inspired by his exciting theory and the strength of his convictions. He purified the PrP protein from infectious material and showed that it was a major component of the prion, and then sequenced the protein.

\section{Japan agrees on target for climate curbs}

[Tокуо] A very public tussle between Japan's trade and environment ministries came to an end this week with the belated announcement that the country will support a worldwide average target of reducing greenhouse gas emissions by 5 per cent from 1990 levels between 2008 and 2012.

For Japan itself the proposal amounts to a reduction in emissions of just 2.5 per cent. The final figure was rounded on by environmentalist groups as too little, too late. It is also likely to create disappointment in European capitals, which had hoped for more from the host of this year's annual conference of the United Nations climate convention in December.

But Japan's Ministry of International Trade and Industry argued until the last minute that commitments to reduce emissions below 1990 levels would hurt Japanese industry. And the United States may take comfort from the announcement.

Japan has argued for a flexible system of greenhouse cuts that imposes fewer obligations on countries that promote energy efficiency and curb population growth. Under its formula, Japan's record of energy efficiency and low population growth entitles the country to halve its 5 per cent target. (See also pages 531 and 532.)

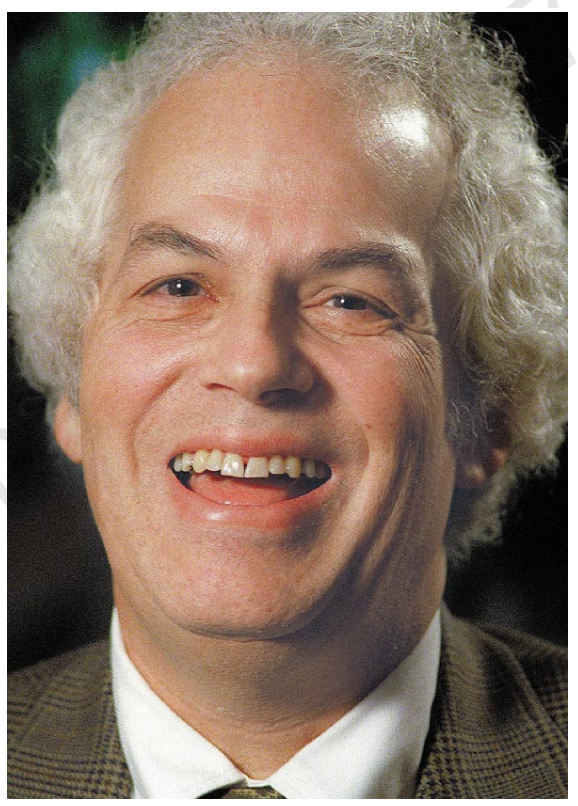

Stanley Prusiner, pictured above on Monday in Bethesda, Maryland, said he felt he had been 'vindicated' by his award of the Nobel prize.

This led to the cloning of the PrP protein by Bruno Oesch and Konrad Basler under the direction of Charles Weissmann in 1985. Weissmann is recognised as having made particularly important conceptual and molecular biology contributions to the "protein-only" hypothesis and the course of prion research over the last 20 years.

If conclusively proven, it is widely agreed that the protein-only hypothesis and Prusiner are fully deserving of a Nobel prize. But scientific issues remain unresolved. Although it is possible to get the disease form of PrP to convert to normal PrP in a test tube (see Nature 375, 698-700; 1995) the resultant material is not infectious.

Perhaps most significantly, there are many strains of TSEs, each with their own characteristics (much like strains of flu). In fact there are too many strains of TSEs to be easily explained by protein conformation alone. Finally, Prusiner himself claims that there is likely to be an as yet unidentified protein accomplice to $\mathrm{PrP}$, which he calls protein $\mathrm{X}$, needed for infectivity.

But Prusiner has certainly been an extraordinary motivator in the field of TSEs over the last 20 years. Indeed, perhaps it is the most productive research that raises as many questions as it answers. Peter Lansbury, a chemist at Harvard University, says that Prusiner "took a medical and biological mystery and changed it into a biophysical and biochemical issue with a very original idea. And that's fabulous".

HarrietColes 